\title{
Associated bacteria of Botryococcus braunii (Chlorophyta)
}

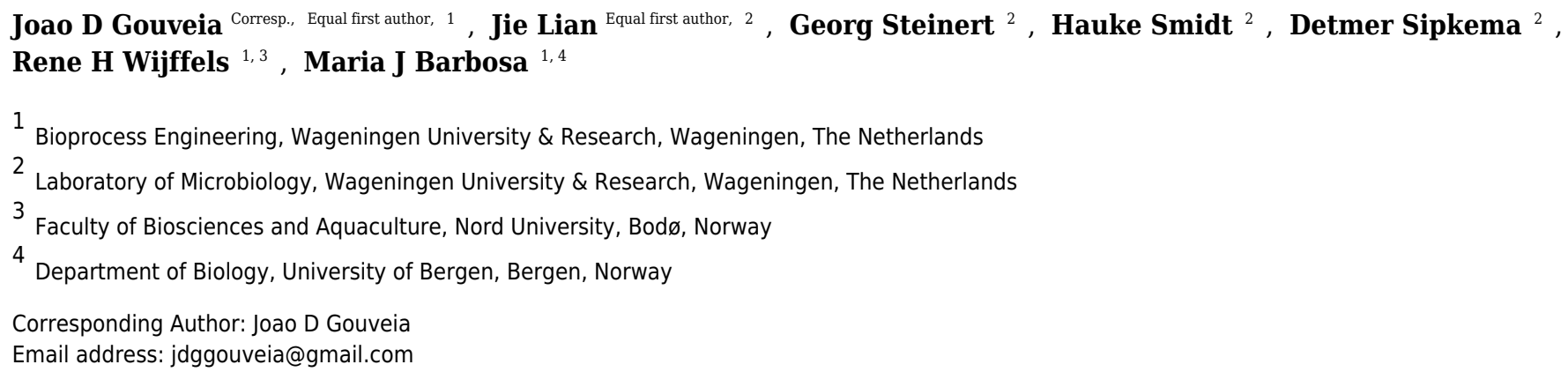

Botryococcus braunii (Chlorophyta) is a green microalga known for producing hydrocarbons and exopolysaccharides. Improving the biomass productivity of $B$. braunii and hence, the productivity of the hydrocarbons and of the exopolysaccharides, will make $B$. braunii more attractive for industries. Microalgae usually cohabit with bacteria which leads to the formation of species-specific communities with environmental and biological advantages. Bacteria have been found and identified with a few $B$. braunii strains, but little is known about the bacterial community across the different strains. A better knowledge of the bacterial community of $B$. braunii will help to optimize the biomass productivity, hydrocarbons and exopolysaccharide accumulation. To better understand the bacterial community diversity of $B$. braunii, we screened 12 strains from culture collections. Using $16 \mathrm{~S}$ rRNA gene analysis by MiSeq we described the bacterial diversity across twelve $B$. braunii strains and identified possible shared communities. We found three bacterial families common to all strains: Rhizobiaceae, Bradyrhizobiaceae and Comamonadaceae. Additionally, the results also suggest that each strain has its own specific bacteria that may be the result of long-term isolated culture. 


\section{Associated bacteria of Botryococcus 2 braunii (Chlorophyta)}

3

4 Joao D. Gouveia ${ }^{*}$, Jie Lian ${ }^{2}$, Georg Steinert ${ }^{2}$, Hauke Smidt ${ }^{2}$, Detmer Sipkema ${ }^{2}$, Rene H. 5 Wijffels ${ }^{1,3}$, Maria J. Barbosa ${ }^{1,4}$

$6 \quad{ }^{1}$ Bioprocess Engineering, Wageningen University \& Research, AlgaePARC, PO Box 16, 6700

7 AA, Wageningen, The Netherlands

$8{ }^{2}$ Laboratory of Microbiology, Wageningen University \& Research, Stippeneng 4, 6708 WE,

9 Wageningen, The Netherlands

$10{ }^{3}$ Faculty of Biosciences and Aquaculture, Nord University, N-8049, Bodø, Norway

$11{ }^{4}$ Department of Biology, University of Bergen, PO Box 7803, 5006 Bergen, Norway

12

$13 *$ Corresponding author: jdggouveia[a]gmail.com, 


\section{Abstract}

22 Botryococcus braunii (Chlorophyta) is a green microalga known for producing hydrocarbons and

23 exopolysaccharides. Improving the biomass productivity of $B$. braunii and hence, the productivity 24 of the hydrocarbons and of the exopolysaccharides, will make B. braunii more attractive for 25 industries. Microalgae usually cohabit with bacteria which leads to the formation of species26 specific communities with environmental and biological advantages. Bacteria have been found and 27 identified with a few B. braunii strains, but little is known about the bacterial community across 28 the different strains. A better knowledge of the bacterial community of B. braunii will help to 29 optimize the biomass productivity, hydrocarbons and exopolysaccharide accumulation. To better 30 understand the bacterial community diversity of B. braunii, we screened 12 strains from culture 31 collections. Using 16S rRNA gene analysis by MiSeq we described the bacterial diversity across 32 twelve B. braunii strains and identified possible shared communities. We found three bacterial 33 families common to all strains: Rhizobiaceae, Bradyrhizobiaceae and Comamonadaceae. 34 Additionally, the results also suggest that each strain has its own specific bacteria that may be the 35 result of long-term isolated culture. 


\section{Introduction}

38 In recent decades many studies have focused on the physiology and cultivation process of several microalgae with potential for large scale production (Blanken et al., 2016; Cabanelas et al., 2016; Grima et al., 1999; Posten, 2009; Ugwu et al., 2005). One microalga of interest for large scale cultivation is $B$. braunii because it can produce and secrete long chain hydrocarbons and exopolysaccharides (EPS) (Dayananda et al., 2007; Fernandes et al., 1989; Metzger and Largeau, 2005). Hydrocarbons are naturally occurring compounds consisting entirely of hydrogen and carbon, and are one of the most important energy resources (Timmis and Qin, 2010) B. braunii is differentiated into different races (race A, B, L and S) depending on the type of hydrocarbons secreted (Kawachi et al., 2012; Metzger and Largeau, 2005). Race A strains synthesize oddnumbered alkadienes and trienes $\left(\mathrm{C}_{25}\right.$ to $\left.\mathrm{C}_{31}\right)$, race $\mathrm{B}$ strains synthesize isoprenoid type compounds termed botryococcenes $\left(\mathrm{C}_{30}\right.$ to $\left.\mathrm{C}_{37}\right)$, and methylated squalenes $\left(\mathrm{C}_{31}\right.$ to $\left.\mathrm{C}_{34}\right)$, race $\mathrm{L}$ strains synthesize lycopadiene $\left(\mathrm{C}_{40}\right)$, and race $\mathrm{S}$ strains synthesize $\mathrm{C}_{18}$ epoxy- $n$-alkanes and $\mathrm{C}_{20}$ saturated n-alkanes (Dayananda et al., 2007; Eroglu et al., 2011; Kawachi et al., 2012; Metzger and Largeau, 2005). EPS can have a range of applications, for example it can be applied as stabilisers and gelling agents in food products. In addition, it has applications in the pharmaceutical and cosmeceutical industries (Borowitzka, 2013; Buono et al., 2012; Donot et al., 2012). B. braunii comprises of a variety of strains from diverse parts of the world. The strains can differ in the hydrocarbon and exopolysaccharide content (Allard and Casadevall, 1875; Dayananda et al., 2007; Eroglu et al., 2011; Gouveia et al., 2017; Metzger et al., 1988; Moutel et al., 1855; Volova et al., 1998; Wolf, 1983).

Bacteria can grow in close proximity to the microalgal cells due to the presence of EPS substances secreted by the microalgae (Bell and Mitchell, 1972). The presence of bacteria within, or close to this EPS layer can lead to mutually beneficial interactions as well as interactions that are antagonistic in nature. Beneficial interactions for microalgae normally provide environmental advantages, such as nutrient exchange and community resilience to invasion by other species (Eigemann et al., 2013; Hays et al., 2015; Jasti et al., 2005; Ramanan et al., 2015). Antagonistic interactions will usually result in inhibition of the microalgal growth, either causing cell lysis, or directly competing for nutrients (Cole, 1982; Cooper and Smith, 2015; Segev et al., 2016). Studies investigating interactions of microalgae with bacteria show how important these interactions can 
67 be for the cultivation process (Guerrini et al., 1998; Kazamia et al., 2012; Kim et al., 2014; Windler 68 et al., 2014). Understanding the interactions of microalgae and bacteria, and how it can enhance 69 the cultivation for industrial process, could lead to increased biomass productivity.

70 So far the bacterial community of B. braunii species is described in only a few studies. The earliest work is from Chirac and colleagues who described the presence of Pseudomonas sp. and Flavobacterium sp. in two strains of B. braunii (Chirac et al., 1982). Rivas and colleagues identified in the B. braunii UTEX strain the presence of Pseudomonas sp. and Rhizobium sp. (Rivas et al., 2010). One study using the B. braunii Ba10 strain showed the presence of rod shaped bacteria in the rim of the colony aggregations and proposed it is as growth promoting bacteria closely related to Hyphomonadaceae spp. (Tanabe et al., 2015). One important finding was that $B$. braunii is a vitamin $\mathrm{B}_{12}$ autotroph, so it does not depend on bacteria for the synthesis of this important metabolite (Tanabe et al., 2014). A more recent study using a B. braunii (race B) strain, revealed the presence of several Rhizobiales such as Bradyrhizobium, and the presence of Bacteroidetes sp (Sambles et al., 2017). So far, all studies have focused on only a few strains making it difficult to have a good overview of what bacterial community dominates $B$. braunii.

In this study we looked at twelve strains of B. braunii obtained from several culture collections to investigate the bacterial community composition that is associated with $\mathrm{B}$. braunii.

\section{Experimental Procedure}

\section{Strain collections and media preparation}

Twelve B. braunii strains were obtained from culture collections (Table 1) and transferred to Erlenmeyer flasks with modified Chu 13 medium (Largeau et al., 1980) without citric acid or vitamins, with the following composition: $1200 \mathrm{mg} \mathrm{L}^{-1} \mathrm{KNO}_{3}, 200 \mathrm{mg} \mathrm{L}^{-1} \mathrm{MgSO}_{4} \cdot 2 \mathrm{H}_{2} 0,108 \mathrm{mg}$ $\mathrm{L}^{-1} \mathrm{CaCl}_{2} .2 \mathrm{H}_{2} \mathrm{O}, 104.8 \mathrm{mg} \mathrm{L}^{-1} \mathrm{~K}_{2} \mathrm{HPO}_{4}, 20 \mathrm{mg} \mathrm{L}^{-1} \mathrm{Fe}-\mathrm{Na}_{2}$ EDTA, $9.4 \mu \mathrm{g} \mathrm{L}^{-1} \mathrm{Na}_{2} \mathrm{O}_{4} \mathrm{Se}, 2.86 \mathrm{mg} \mathrm{L}^{-}$ ${ }^{1} \mathrm{H}_{3} \mathrm{BO}_{3}, 1.8 \mathrm{mg} \mathrm{L}^{-1} \mathrm{MnSO}_{4} .4 \mathrm{H}_{2} \mathrm{O}, 220 \mu \mathrm{g} \mathrm{L}-1 \mathrm{ZnSO}_{4} .7 \mathrm{H}_{2} \mathrm{O}, 90 \mu \mathrm{g} \mathrm{L}-1 \mathrm{CoSO}_{4} .7 \mathrm{H}_{2} \mathrm{O}, 80 \mu \mathrm{g} \mathrm{L}-1$ $\mathrm{CuSO}_{4} .5 \mathrm{H}_{2} \mathrm{O}, 60 \mu \mathrm{g} \mathrm{L}-1 \mathrm{Na}_{2} \mathrm{MoO}_{4} \cdot 2 \mathrm{H}_{2} \mathrm{O}, 10 \mu \mathrm{L}^{-1} \mathrm{H}_{2} \mathrm{SO}_{4}$. The final $\mathrm{pH}$ was adjusted to $\mathrm{pH} 7.2$ with $\mathrm{NaOH}$ and $\mathrm{NaHCO}_{3}$ was added to a final concentration of $5 \mathrm{mM}$. The 12 strains were grown in Infors HT Multriton incubators in $250 \mathrm{~mL}$ conical flasks and a volume of $150 \mathrm{~mL}$. The temperature was set at $23^{\circ} \mathrm{C}$, with $2.5 \% \mathrm{CO}_{2}$ enriched air and shaking at $90 \mathrm{rpm}$. Illumination was 
96 provided by Phillips lamps FL-Tube L 36W/77, with $150 \mu \mathrm{mol}$ photon $\mathrm{m}^{-2} \mathrm{sec}^{-1}$, and a light:dark

97 photoperiod of 18:6 h. Flasks were inoculated with B. braunii growing in the active growing phase, 98 such that the initial absorbance at $680 \mathrm{~nm}$ was 0.2 . The Erlenmeyer flasks were capped with 99 aeraseal sterile film (Alphalabs). Samples were taken at day 1, 4, 8 and 11, for 16S rRNA gene 100 analyses.

\section{DNA extraction}

103 On sampling days, $5 \mathrm{~mL}$ of fresh culture was harvested with sterilized membrane filters $(0.2 \mu \mathrm{m}$, Millipore) using a vacuum apparatus. The filters were cryopreserved in $-80{ }^{\circ} \mathrm{C}$ until further processing. DNA was extracted from the cryopreserved filters that were cut into small pieces with a sterile scissor. Filter pieces were transferred to a $2 \mathrm{~mL}$ sterilized tube with zirconia/silica beads (Biospecs), and $1 \mathrm{~mL}$ S.T.A.R buffer (Roche, USA) was added. Cells were homogenized for two rounds of 45 seconds, at the speed of $5500 \mathrm{rpm}$ with Precellys (Bertin Technologies). Then DNA was extracted using the Maxwell 16 Tissue LEV Total RNA purification kit (Promega, USA) with aid of the Maxwell 16 instrument (Promega, USA). The purity and quantity of DNA was examined

111 by electrophoresis on a $1 \%$ agarose gel and measured with a Nanodrop (ND1000, Thermo Fisher

112 Scientific Inc., Wilmington). The extracted DNA was stored at $-20^{\circ} \mathrm{C}$ until further use.

\section{S rRNA gene amplification and Miseq sequencing}

114 Amplicons from the V1-V2 region of 16S rRNA genes were generated by a two-step PCR strategy 115 consisting of a forward primer (27F-DegS = 5' GTTYGATYMTGGCTCAG 3' where $\mathrm{M}=\mathrm{A}$ or $116 \mathrm{C} ; \mathrm{R}=\mathrm{A}$ or $\mathrm{G} ; \mathrm{W}=\mathrm{A}$ or $\mathrm{T} ; \mathrm{Y}=\mathrm{C}$ or $\mathrm{T})$ and an equimolar mixture of reverse primers $(338 \mathrm{R} \mathrm{I}=$ 5'GCWGCCTCCCGTAGGAGT 3' and II = 5' GCWGCCACCCGTAGGTGT 3' where $\mathrm{M}=\mathrm{A}$ or $\mathrm{C} ; \mathrm{R}=\mathrm{A}$ or $\mathrm{G} ; \mathrm{W}=\mathrm{A}$ or $\mathrm{T} ; \mathrm{Y}=\mathrm{C}$ or $\mathrm{T}$ ). Eighteen bp Universal Tags 1 and 2 (Unitag1= GAGCCGTAGCCAGTCTGC; Unitag2= GCCGTGACCGTGACATCG) were appended at the 5' end of the forward and reverse primer, respectively (Bogert et al., 2011; Daims et al., 1999; Tian et al., 2016). The first PCR mix $(50 \mu \mathrm{L})$ contained $10 \mu \mathrm{L} 5 \times$ HF buffer (Thermo ScientificTM, the Netherlands), $1 \mu \mathrm{L}$ dNTP Mix (10 mM; Promega, Leiden, the Netherlands), $1 \mathrm{U}$ of Phusion ${ }^{\circledR}$ Hot

123 Start II High-Fidelity DNA polymerase (Thermo ScientificTM), $1 \mu \mathrm{M}$ of 27F-DegS forward 124 primer, $1 \mu \mathrm{M}$ of 338R I and II reverse primers, $1 \mu \mathrm{L}$ template DNA and $32.5 \mu \mathrm{L}$ nuclease free 125 water. Amplification included an initial denaturation at $98^{\circ} \mathrm{C}$ for $30 \mathrm{sec} ; 25$ cycles of denaturation 
126 at $98^{\circ} \mathrm{C}$ for $10 \mathrm{sec}$; annealing at $56^{\circ} \mathrm{C}$ for $20 \mathrm{sec}$ and elongation at $72^{\circ} \mathrm{C}$ for $20 \mathrm{sec}$; and a final

127 extension at $72^{\circ} \mathrm{C}$ for $10 \mathrm{~min}$. The PCR product size was examined by $1 \%$ gel electrophoresis.

128 The second PCR mix $(100 \mu \mathrm{L})$ contained $62 \mu \mathrm{L}$ nuclease free water, $5 \mu \mathrm{L}$ of PCR1 product, 20

$129 \mu \mathrm{L} 5 \times$ HF buffer, $2 \mu \mathrm{L}$ dNTP Mix, 2 U of Phusion ${ }^{\circledR}$ Hot Start II High-Fidelity DNA polymerase,

$130500 \mathrm{nM}$ of a forward and reverse primer equivalent to the Unitag1 and Unitag2 sequences

131 respectively, each appended with an $8 \mathrm{nt}$ sample specific barcode. Amplification included an initial

132 denaturation at $98^{\circ} \mathrm{C}$ for $30 \mathrm{sec} ; 5$ cycles of denaturation at $98^{\circ} \mathrm{C}$ for $10 \mathrm{sec}$, annealing at $52^{\circ} \mathrm{C}$ for

$13320 \mathrm{sec}$ and elongation at $72^{\circ} \mathrm{C}$ for $20 \mathrm{sec}$; and a final extension at $72^{\circ} \mathrm{C}$ for $10 \mathrm{~min}$.. The

134 concentration of PCR products was quantified with a Qubit Fluorometer (Life Technologies,

135 Darmstadt, Germany) in combination with the dsDNA BR Assay kit (Invitrogen, Carlsbad, CA,

136 USA). Purified products were then pooled in equimolar amounts of $100 \mathrm{ng} \mu \mathrm{L}^{-1}$ and sequenced on

137 a MiSeq platform (GATC-Biotech, Konstanz, Germany).

\section{Processing MiSeq data}

139 Data was processed using the Quantitative Insights into Microbial Ecology (QIIME) 1.8.0. In

140 short, paired-end libraries were filtered to contain only read pairs perfectly matching barcodes.

141 Low quality or ambiguous reads were removed and then chimeric reads were removed and

142 checked. Sequences with less than $0.1 \%$ were discarded. Remaining filtered sequences were

143 assigned into Operational Taxonomy Units (OTUs) at 97\% threshold using an open reference

144 method and a customized SILVA 16S rRNA gene reference (Quast et al., 2013). Seven samples

145 from day 4 were removed from the results due to contamination during the PCR steps: AC755,

146 AC759, AC760, AC767, AC768, CCAP and UTEX572. The 16S rRNA gene dataset obtained in

147 this study is deposited in the Sequence Read Archieve (SRA), NCBI with accession number

148 SRP102970.

149 Microbial community analysis

150 For the interpretation of the microbial community data on family level, the Operational Taxonomic

151 Unit (OTU) abundance table was converted to relative abundance and visualized as heatmaps using

152 JColorGrid (Joachimiak et al., 2006). Ordination analyses to estimate the relationship of the $B$.

153 braunii strains based on dissimilarity of the microbial community compositions among the

154 individual samples was performed for, a) all strains of B. braunii used in this study, b) all strains

155 received from ALGOBANK-CAEN culture collection. For both analysis a standardized 97\% OTU 
156 table (decostand function, method $=$ hellinger $)$ and the nMDS function metaMDS (distance = 157 Bray-Curtis) from the vegan package in $\mathrm{R}$ was used ( $\mathrm{R}$ version 3.0.2) (Oksanen et al., 2016; $\mathrm{R}$

158 Core Team, 2014). Betadispersion and a permutation test were performed to test homogeneity 159 dispersion within a group of samples. Adonis from the vegan package in R (v.3.0.2) was used to 160 test significant differences in bacterial community between strains. Hierarchical clustering analysis 161 was performed using hclust function in $\mathrm{R}$ using method $=$ average.

\section{Results}

163 Fig. 1 shows the bacterial families with a relative abundance above $1 \%$ and a total of four bacterial 164 phyla associated with $B$. braunii strains. The four phyla found associated with $B$. braunii are the 165 Bacteroidetes, Gemmatimonadetes, Planctomycetes and Proteobacteria. Proteobacteria is the 166 predominant bacterial phylum and representatives of this taxon are found in all 12 strains. 167 Bacteroidetes is found in all strains with exception to strains AC761, AC768 and CCAP. 168 Gemmatimonadetes is found only in the CAEN culture (with AC prefix) strains with exception to 169 AC755. Planctomycetes is found in AC760, CCALA, K1489, Showa and UTEX strains. Three 170 families are found across all $12 \mathrm{~B}$. braunii strains and all are Proteobacteria. These are the 171 Rhizobiaceae, Bradyrhizobiaceae and Comamonadaceae. Rhizobiaceae is represented by 1 to 59 $172 \%$ of the bacterial reads. Bradyrhizobiaceae was found within the 1 to $8 \%$ range. 173 Comamonadaceae was found between 1 and $5 \%$. Two families of bacteria are only found in the 174 strains obtained from the CAEN culture collection: Erythrobacteraceae with bacterial reads 175 ranging from 1 to $29 \%$ and Rhodocyclaceae with 1 to $18 \%$.

Fig. 1176

177 Some families of bacteria are particularly dominant in specific strains. Sinobacteraceae is 178 dominant in CCAP with relative abundances ranging from 59 to $78 \%$. Planctomycetaceae is 179 dominant in K1489 strain with relative abundances between 46 and $51 \%$. Rhizobiaceae is 180 dominant in AC761 with relative abundances between 55 and $64 \%$. Other families of bacteria 181 become dominant as the cultures become older. Rhodobacteraceae is present in AC755 strain with 182 relative abundances ranging from $28 \%$ at day 1 to $40 \%$ at day 11 . Sphingomonadaceae is present 183 in UTEX with $10 \%$ at day 1 and increases its presence to $47 \%$ at day 11. Chytophagaceae is 184 dominant in CCALA strain with relative abundance ranging from $10 \%$ at day 1 to $52 \%$ at day 11. 
185 Because we found three common families across all strains, we wanted to investigate in more 186 detail the bacterial composition in these selected families and see if we could identify an unique 187 microorganism present in all strains. Therefore we zoomed in and looked at the Operational 188 Taxonomy Units (OTUs) distribution belonging to the three families: Rhizobiaceae, 189 Bradyrhizobiaceae and Comamonadaceae. In addition, we picked the OTUs found only in the 190 strains obtained from the CAEN culture collection which belong to two families: 191 Erythrobacteraceae and Rhodocyclaceae. The most abundant OTUs were selected and a total of 19228 OTUs were investigated. From Fig. 2 it is clear that there is not an OTU that is found across all 193 strains but rather each family comprises of several different OTUs. The second important 194 observation is that CCAP strain has no representative OTUs for Bradyrhizobiaceae and 195 Rhizobiaceae in the most abundant OTUs. The most represented family taxon is Rhizobiaceae 196 with 12 OTUs. From the three families found in the 12 strains, OTU 233 assigned to the genus 197 Rhizobium has the highest OTU frequency abundance with $10 \%$ and is present in 7 out of 12 198 strains. The OTUs 143, 88 and 131 assigned to the genus Shinella are present in 9 out of 12 strains. 199 The OTUs 477, 475 and 484 assigned to the genus Bosea cover 11 out of 12 strains. From the two 200 families found only in the cultures originating from the CAEN culture collection, OTUs 333 and 201539 are found in all seven CAEN strains with an assigned genus Porphyrobacter and 202 Methyloversatilis respectively.

Fig. 2203

204 The most abundant OTUs (as listed in Fig. 2) were subjected to a Blast search against the NCBI 205 database to infer their nearest neighbours (Table 2). OTUs 88, 115, 143 and 233 are similar in their nearest neighbours with four different Rhizobium spp. as candidates. Similar blast results are seen 207 also for OTUs 566 and 567 with the nearest neighbours being Hydrogenophaga spp. The OTUs 208819 and 832 with Dyadobacter spp. as nearest neighbour dominate CCALA bacterial community. 209 Some OTUs show different species as closest neighbours such as OTUs 45 and 69 with 210 Frigidibacter albus, Paracoccus sediminis and Nioella nitratireducens as neighbours. The OTU 211415 with high abundance in K1489 belonging to Planctomycetaceae, has as closest neighbours 212 uncultured bacterium and third closest neighbour uncultured Planctomyces spp. with the latter 213 showing $87 \%$ identity. The OTU 333 present only in the strains from CAEN culture collection, 
214 has $100 \%$ identity with Sphingomonas as closest two neighbours, and third neighbour, also with

$215100 \%$, identity being Porphyrobacter.

217 Non-metric multidimensional scaling ordination was performed for the 12 strains to determine the 218 bacterial community dissimilarities (Fig 3a). B. braunii strains from the CAEN culture collection 219 cluster together when compared to the other strains indicating these strains are similar to each other 220 in bacterial community composition. This is supported by hierarchical cluster analysis showing 221 CAEN strains in their own cluster (Supplementary Fig. 1). The strains K1489, UTEX, CCAP, 222 CCALA and Showa represent separate clusters. The homogeneity of dispersion within each strain 223 with 1000 permutations show no significant difference $(F=0.323)$. Using adonis to test for bacterial 224 community similarities between all strains, the results show that the bacterial communities are 225 significantly different $\left(\mathrm{DF}=11\right.$, Residuals $\left.=28, \mathrm{R}^{2}=0.921, \mathrm{P}=0.001\right)$. Fig $3 \mathrm{~b}$ zooms in to the 226 CAEN culture collection strains. Races A, B and L are subdivisions of B. braunii according to the 227 type of hydrocarbons produced. No clustering by type of hydrocarbons produced was seen by the 228 distribution of the race B and race L strains which are found mixed, namely race B AC759 and 229 AC761 with race L AC765 and AC768. Similarly, the bacterial community between CAEN strains 230 are significantly different $(\mathrm{DF}=6$, Residuals $=16, \mathrm{R} 2=0.904, \mathrm{P}=0.001)$.

Fig. 3231 


\section{Discussion}

234 It is evident that B. braunii possesses a highly diverse bacterial community as seen by the range

235 of bacterial phyla and families present in all the strains used in this study (Fig. 1 (for a more 236 comprehensive list see Supplementary Fig. 2)).

237 From the bacterial community analysis (Fig. 3a,b), it appears that each B. braunii strain has a 238 specific bacterial community and no OTU is shared between all strains. The strains from the CAEN 239 culture collection cluster together while B. braunii strains from other culture collections appear as 240 separate groups. This implies that the culture collection from which the strain was obtained could 241 potentially have an effect. With this study we are not able to really deduce the potential impact of 242 the culture collection on the bacterial community because the experimental design was not set-up 243 to do so. The presence of weak (within a culture collection) and strong (between culture 244 collections) migration barriers may explain the bacterial profiles as obtained in our study and they 245 may be a result of historical contingencies (Fenchel, 2003) rather than pointing towards highly 246 specific interactions for a large number of OTUs. OTUs 539 and 333 are only found with the 247 CAEN cultures and contributes towards these strains clustering in close proximity. OTU 333 is 248 especially high in relative abundance and contributes to the distinctive clustering of the CAEN culture collection strains. The remaining strains also contain their specific OTUs that contribute towards their own clustering: OTU 819 and 832 with CCALA, OTU 310 with UTEX and K1489 with OTU 415 . The bacterial community between three race $\mathrm{B}$ and three race $\mathrm{L}$ are mixed together (Fig. 3b). Therefore no correlation was found between bacterial community and the type of hydrocarbons produced between the two races. Similar observations were made in another study using six strains of $B$. braunii in which the authors did not find a correlation between the bacteria and type of hydrocarbon produced (Chirac et al., 1985).

Three bacterial families were found to be present with all twelve strains of B. braunii: Bradyrhizobiaceae, Rhizobiaceae, and Comamonadaceae. Two families were found abundantly only in the strains from the CAEN culture collection: Erythrobacteraceae and Rhodocyclaceae. The OTUs 88, 115, 143 and 233 blast hits show these are related to Rhizobium spp. (Table 2). Rhizobium spp. are known to form nodules in the roots of several plants within the family of

261 legumes and are best known for nitrogen fixation. Nitrogen fixing bacteria were investigated in

262 association with microalgae and it has been shown that they can enhance microalgae growth 
263 (Hernandez et al., 2009). Rhizobium spp. associated with B. braunii could have a similar role. 264 Rivas et al. (2010) also found a Rhizobium sp. associated with B. braunii in particular UTEX 265 LB572, and Kim et al. (2014) showed the presence of Rhizobium sp. with B. braunii 572. Sambles 266 et al (2017) identified Rhizobium sp. closely associated with B. braunii after submitting the 267 cultures through a wash step and antibiotic treatment. Recent studies also shows Rhizobium spp. 268 present with Chlamydomonas reinhardtii, Chlorella vulgaris and Scenedesmus spp. (Kim et al., 269 2014). Rhizobium spp. seem important to B. braunii strains as it appears in all 12 strains with more 270 prominence in the CAEN cultures and K1489 with three to four OTUs (Fig. 2). For the remaining 271 strains CCALA, CCAP, Showa and UTEX, Rhizobium spp. is represented only with one OTU.

272 OTU 475 from Bradyrhizobiaceae family shows $100 \%$ similarity with the species 273 Hyphomicrobium nitrativorans as the two closest neighbours and is present in 10 out of $12 \mathrm{~B}$. 274 braunii strains. H. nitrativorans is a known denitrifier isolated from a seawater treatment facility 275 (Martineau et al., 2013). Denitrification is the process of reducing nitrate into a variety of gaseous 276 compounds with the final being dinitrogen. Because denitrification mainly occurs in the absence 277 of oxygen it is unlikely that this is happening within our cultures that are well oxygenated. The $3^{\text {rd }}$ 278 closest neighbour for OTU 475 is Bosea lathyri and is associated with root nodules legumes 279 (Meyer et al., 2012).

280 OTUs 555, 566 and 567 from Comamonadaceae family, appeared in seven out of twelve strains. 281 The three closest neighbours of OTU 555 were Variovorax spp. and for OTUs 566 and 567 these 282 were Hydrogenophaga spp., Variovorax and Hydrogenophaga spp. are not known for being 283 symbionts but may be able to support ecosystems by their ability to degrade toxic compounds and 284 assist in nutrient recycling, therefore potentially producing benefits to other microorganisms 285 (Satola et al., 2013; Yoon et al., 2008). Comamonadaceae also appeared as one of the main bacteria 286 families associated with cultivation of microalgae in bioreactors using a mix of fresh water and 287 municipal water as part of a water treatment strategy (Krustok et al., 2015).

288 Erythrobacteraceae and Rhodocyclaceae were only found in the strains from CAEN culture 289 collection. OTU 333 (Erythrobacteraceae) first two closest neighbours are from Sphingomonas 290 spp., and third closest neighbour is Porphyrobacter spp. isolated from water in a swimming pool. 291 Most Porphyrobacter spp. isolated originate from aquatic environments (Tonon et al., 2014) and 292 are associated with fresh water sediments (Fang et al., 2015). Porphyrobacter spp. have also been 
293 associated with other microalgae such as Tetraselmis suecica (Biondi et al., 2016). OTU 539

294 (Rhodocyclaceae) second and third closest neighbour is Methyloversatilis discipulorum which is 295 a bacteria found in biofilms formation in engineered freshwater installations (Kooij et al., 2017).

296 It is not clear why OTU 333 and 539 are specifically found only in the strains originating from the 297 CAEN culture collection, but it could be an introduced species during handling. None the less, 298 these two OTUs are present in high relative abundance (Fig. 2), and would be interesting to know 299 if they have a positive or negative influence on the growth of the CAEN strains. It would be 300 interesting to confirm such statement by attempting the removal of these OTUs and investigate the 301 biomass growth.

302 Sinobacteraceae is dominant in CCAP (Fig. 1). This family was proposed in 2008 with the 303 characterization of a bacteria from a polluted soil in Chi (Zhou et al., 2008). A recent bacteria 304 related to hydrocarbon degradation shows similarities with Sinobacteraceae (Gutierrez et al., 305 2013). OTU 63 is highly abundant in CCAP and could have a negative impact in the cultivation 306 of CCAP strain by reducing its hydrocarbon content.

307 The Bactoroidetes family Cytophagaceae dominates the culture CCALA at later stages of growth

308 (Fig. 1). Cytophagaceae has also been found present in laboratory scale photobioreactor 309 cultivation using wastewater for production of microalgae biomass (Krustok et al., 2015). The two 310 OTUs that dominate the bacterial community in CCALA are OTU 819 and OTU 832. The Blast 311 search on NCBI database approximates these two OTUs as Dyadobacter spp. which have also 312 been found co-habiting with Chlorella spp. (Otsuka et al., 2008).

313 Planctomycetaceae dominates the bacterial community in K1489 strain (Fig. 1) with one OTU 314 415. This family can be found in freshwater biofilms and also strongly associated with macroalga 315 (Abed et al., 2014; Lage and Bondoso, 2014). Species in this family could possibly be involved in 316 metallic-oxide formation and be co-players in sulphate-reduction with the latter also involving a 317 sulphur-reducing bacteria (Shu et al., 2011).

318 Rhodobacteraceae is present with up to $55 \%$ of bacterial relative abundance in AC755. Members 319 of this family have been also isolated from other microalgae, namely Chlorella pyrenoidosa and 320 Scenedesmus obliquus (Schwenk et al., 2014). The OTUs 45 and 69 blast searches in NCBI 321 database show the closest neighbours to be Frigidibacter albus, Paracoccus sediminis and Nioella 
322 nitratireducens (Table 2). All three neighbours were isolated from water environments (Li and 323 Zhou, 2015; Pan et al., 2014).

324 Sphingomonadaceae is mostly found in freshwater and marine sediments (Newton et al., 2011). 325 OTUs 302, 310 and 355 from this family were found in 6 out of 12 strains above $1 \%$ relative 326 abundance. OTU 310 is only found in the UTEX strain with Sphingomonas spp. as the two closest 327 neighbours. Sphingomonas spp. are shown to co-habit with other microalgae such as Chlorella 328 sorokiniana and C. vulgaris (Ramanan et al., 2015; Watanabe et al., 2005). Sphingomonas spp. 329 have been shown to be able to degrade polycyclic aromatic hydrocarbons (Tang et al., 2010) and 330 could possibly be degrading the hydrocarbons secreted by B. braunii as its carbon source.

331 Another characteristic of many bacteria is the ability to produce EPS such as species from the 332 Rhizobiaceae and Bradyrhizobiaceae family (Alves et al., 2014; Bomfeti et al., 2011; Freitas et 333 al., 2011). This characteristic could play a role on the colony aggregation of B. brauniii as EPS is 334 known to be essential for biofilm formation (Flemming et al., 2007). Therefore it would be 335 interesting in the future to study this possible relationship as B. braunii is a colony forming 336 organism. Such studies could involve the introduction of bacteria associated with colony formation 337 such as Terramonas ferruginea as it has been associated with inducing flocculation in C. vulgaris 338 cultures (Lee et al., 2013).

339 With the present high microbial diversity, B. braunii shows qualities in resilience towards 340 microbial activity, probably due to its colonial morphology and protective phycosphere made of 341 hydrocarbons and EPS (Weiss et al., 2012). A number of microbes are potentially beneficial such 342 as Rhizobium spp. which have been shown to have a positive effect on the biomass productivities 343 of B. braunii UTEX (Rivas et al., 2010), and Hydrogenophaga with the ability to degrade toxic 344 compounds (Yoon et al., 2008). There are also microbes that may cause detrimental effects on 345 hydrocarbon productivities of B. braunii such as Sphingomonas spp. (OTU 310) with its ability to 346 degrade hydrocarbons (Tang et al., 2010). The removal of such detrimental microbes could 347 enhance cultivation allowing more nitrogen available for biomass production and increase 348 hydrocarbon accumulation of B. braunii as well as EPS production at larger industrial scale. 


\section{Conclusion}

351 B. braunii can host a diverse microbial community and it is likely that some form of interaction is 352 taking place with the members from the Rhizobiaceae, Bradyrhizobiaceae and Comamonadaceae 353 family, which all belong to the phylum Proteobacteria. There is not a specific bacterial community 354 correlated to the different types of hydrocarbons produced by race $\mathrm{B}$ and $\mathrm{L}$ and mostly likely also 355 not race A. B. braunii has many strains and each seems to have its own species-specific bacterial 356 community. With a diverse microbial community present, it is also likely that some bacteria are 357 having antagonistic effects on B. braunii such as competition with nutrients and degradation of 358 hydrocarbons. Botryococcus is a microalgae of high scientific interest and it is important to 359 understand better the associated bacteria. Botryococcus-associated bacteria are hard to get rid of 360 (Gouveia, J. unpublished data) and therefore it is important to start mass cultivation without those 361 bacteria that are most harmful to the process. 
364 References

365

366

367

368

369

370

371

372

373

374

375

376

377

378

379

380

381

382

383

384

385

386

387

388

389

390

391

392

393

394

395

396

397

398

399

400

401

402

403

404

405

406

Abed, R.M.M., Al-Kharusi, S., Prigent, S., Headley, T., 2014. Diversity, distribution and hydrocarbon biodegradation capabilities of microbial communities in oil-contaminated cyanobacterial mats from a constructed wetland. Plos One 9.

Allard, B., Casadevall, E., 1875. Carbohydrate composition and characterization of sugars from the green microalga Botryococcus braunii. Phytochemistry 29.

Alves, C., M, L., de Souza, J.A.M., Varani, A., 2014. The Prokaryotes: Alphaproteobacteria and Betaproteobacteria. Heidelberg: Springer Berlin Heidelberg, Berlin.

Bell, W., Mitchell, R., 1972. Chemotactic and growth responses of marine bacteria to algal extracellular products. Biol. Bull. 143, 265-277.

Biondi, N., Cheloni, G., Tatti, E., Decorosi, F., Rodolfi, L., Giovannetti, L., Viti, C., Tredici, M.R., 2016. The bacterial community associated with Tetraselmis suecica outdoor mass cultures. J. Appl. Phycol. 1-12.

Blanken, W., Schaap, S., Theobald, S., Rinzema, A., Wijffels, R.H., Janssen, M., 2016. Optimizing carbon dioxide utilization for microalgae biofilm cultivation. Biotechnol. Bioeng.

Bogert, B. van den, Vos, W.M. de, Zoetendal, E.G., Kleerebezem, M., 2011. Microarray Analysis and Barcoded Pyrosequencing Provide Consistent Microbial Profiles Depending on the Source of Human Intestinal Samples. Appl Env. Microbiol 77, 2071-2080. https://doi.org/10.1128/AEM.02477-10

Bomfeti, C.A., Florentino, L.A., Guimarães, A.P., Cardoso, P.G., Guerreiro, M.C., Moreira, F.M., 2011. Exopolysaccharides produced by the symbiotic nitrogen-fixing bacteria of leguminosae. Rev. Bras. Ciênc. Solo 35, 657-671.

Borowitzka, M., 2013. High-value products from microalgae: their development and commercialisation. J. Appl. Phycol. 25, 743-756.

Buono, S., Langellotti, A.L., Martello, A., Bimonte, M., Tito, A., Carola, A., Apone, F., Colucci, G., Fogliano, V., 2012. Biological activities of dermatological interest by the water extract of the microalga Botryococcus braunii. Arch. Dermatol. Res. 304, 755-764.

Cabanelas, I.T.D., van der Zwart, M., Kleinegris, D.M.M., Wijffels, R.H., Barbosa, M.J., 2016. Sorting cells of the microalga Chlorococcum littorale with increased triacylglycerol productivity. Biotechnol. Biofuels 9.

Chirac, C., Casadevall, E., Largeau, C., Metzger, P., 1985. Bacterial influence upon growth and hydrocarbon production of the green alga Botryococcus braunii. J. Phycol. 21, 380-387.

Chirac, C., Casadevall, E., Largeau, C., Metzger, P., 1982. Effect of algal strain and of associated bacteria on hydrocarbon productivity from Botryococcus braunii. Comptes Rendus Acad. Sci. Ser. Iii-Sci. Vie-Life Sci. 295, 671-674.

Cole, J.J., 1982. Interactions between bacteria and algae in aquatic ecosystems. Annu. Rev. Ecol. Syst. 13, 291-314.

Cooper, M.B., Smith, A.G., 2015. Exploring mutualistic interactions between microalgae and bacteria in the omics age. Curr. Opin. Plant Biol. 26, 147-153.

Daims, H., Bruhl, A., Amann, R., Schleifer, K.H., Wagner, M., 1999. The domain-specific probe EUB338 is insufficient for the detection of all Bacteria: development and evaluation of a more comprehensive probe set. Syst Appl Microbiol 22, 434-44. 
407

408

409

410

411

412

413

414

415

416

417

418

419

420

421

422

423

424

425

426

427

428

429

430

431

432

433

434

435

436

437

438

439

440

441

442

443

444

445

446

447

448

449

450

Dayananda, C., Sarada, R., Rani, U., M., S., R, T., Ravishankar, G.A., 2007. Autotrophic cultivation of Botryococcus braunii for the production of hydrocarbons and exopolysaccharides in various media. Biomass Bioenergy 31, 87-93.

Donot, F., Fontana, A., Baccou, J.C., Schorr-Galindo, S., 2012. Microbial exopolysaccharides: main examples of synthesis, excretion, genetics and extraction. Carbohydr. Polym. 87, 951-962.

Eigemann, F., Hilt, S., Salka, I., Grossart, H.P., 2013. Bacterial community composition associated with freshwater algae: species specificity vs dependency on environmental conditions and source community. Fems Microbiol. Ecol. 83, 650-63.

Eroglu, E., Okada, S., Melis, A., 2011. Hydrocarbon productivities in different Botryococcus strains: comparative methods in product quantification. J. Appl. Phycol. 23.

Fang, L., Chen, L., Liu, Y., Tao, W., Zhang, Z., Liu, H., Tang, Y., 2015. Planktonic and sedimentary bacterial diversity of Lake Sayram in summer. Microbiologyopen 4, 814-825.

Fenchel, T., 2003. Biogeography for bacteria. Science 301, 925. https://doi.org/10.1126/science. 1089242

Fernandes, H.L., Tome, M.M., Lupi, F.M., Fialho, A.M., Sacorreia, I., Novais, J.M., 1989. Biosynthesis of high concentrations of an exopolysaccharide during the cultivation of the microalga Botryococcus braunii. Biotechnol. Lett. 11, 433-436.

Flemming, H.-C., Neu, T.R., Wozniak, D.J., 2007. The EPS matrix: the "house of biofilm cells." J. Bacteriol. 189, 7945-7947.

Freitas, F., Alves, V.D., Reis, M.A.M., 2011. Advances in bacterial exopolysaccharides: from production to biotechnological applications. Trends Biotechnol. 29, 388-398.

Gouveia, J.D., Ruiz, J., van den Broek, L.A.M., Hesselink, T., Peters, S., Kleinegris, D.M.M., Smith, A.G., van der Veen, D., Barbosa, M.J., Wijffels, R.H., 2017. Botryococcus braunii strains compared for biomass productivity, hydrocarbon and carbohydrate content. J. Biotechnol. 248, 77-86. https://doi.org/10.1016/j.jbiotec.2017.03.008

Grima, E.M., Fernandez, F.G.A., Camacho, F.G., Chisti, Y., 1999. Photobioreactors: light regime, mass transfer, and scaleup. J. Biotechnol. 231-247.

Guerrini, F., Mazzotti, A., Boni, L., Pistocchi, R., 1998. Bacterial-algal interactions in polysaccharide production. Aquat. Microb. Ecol. 15, 247-253.

Gutierrez, T., Green, D.H., Nichols, P.D., Whitman, W.B., Semple, K.T., Aitken, M.D., 2013. Polycyclovorans algicola gen nov., sp. nov., an aromatic hydrocarbon degrading marine bacterium found associated with laboratory cultures of marine phytoplankton. Appl. Environ. Microbiol. 79, 205-214.

Hays, S.G., Patrick, W.G., Ziesack, M., Oxman, N., Silver, P.A., 2015. Better together: engineering and application of microbial symbioses. Curr. Opin. Biotechnol. 36, 40-49.

Hernandez, J.-P., de-Bashan, L.E., Rodriguez, D.J., Rodriguez, Y., Bashan, Y., 2009. Growth promotion of the freshwater microalga Chlorella vulgaris by the nitrogen-fixing, plant growth-promoting bacterium Bacillus pumilus from arid zone soils. Eur. J. Soil Biol., Ecology and application of Azospirillum and other plant growth promoting bacteria (PGPB) 45, 88-93. https://doi.org/10.1016/j.ejsobi.2008.08.004

Hilton, J., Rigg, E., Jaworski, G., 1988. In vivo algal fluorescence, spectral change due to light intensity changes and the automatic characterization of algae. Freshw. Biol. 20, 375-382. https://doi.org/10.1111/j.1365-2427.1988.tb00463.x 
451

452

453

454

455

456

457

458

459

460

461

462

463

464

465

466

467

468

469

470

471

472

473

474

475

476

477

478

479

480

481

482

483

484

485

486

487

488

489

490

491

492

493

494

495

Jasti, S., Sieracki, M.E., Poulton, N.J., Giewat, M.W., Rooney-Varga, J.N., 2005. Phylogenetic diversity and specificity of bacteria closely associated with Alexandrium spp and other phytoplankton. Appl. Environ. Microbiol. 71, 3483-3494.

Joachimiak, M.P., Weisman, J.L., May, B.C., 2006. JColorGrid: software for the visualization of biological measurements. BMC Bioinformatics 7.

Kawachi, M., Tanoi, T., Demura, M., Kaya, K., Watanabe, M.M., 2012. Relationship between hydrocarbons and molecular phylogeny of Botryococcus braunii. Algal Res. 1, 114-119.

Kazamia, E., Czesnick, H., Thi, T.V.N., Croft, M.T., Sherwood, E., Sasso, S., Hodson, S.J., Warren, M.J., Smith, A.G., 2012. Mutualistic interactions between vitamin B12-dependent algae and heterotrophic bacteria exhibit regulation. Environ. Microbiol. 14, 1466-1476.

Kim, B.-H., Ramanan, R., Cho, D.-H., Oh, H.-M., Kim, H.-S., 2014. Role of Rhizobium, a plant growth promoting bacterium, in enhancing algal biomass through mutualistic interaction. Biomass Bioenergy 69, 95-105. https://doi.org/10.1016/j.biombioe.2014.07.015

Kooij, D. van der, Bakker, G.L., Italiaander, R., Veenendaal, H.R., Wullings, B.A., 2017. Biofilm composition and threshold concentration for growth of Legionella pneumophila on surfaces exposed to flowing warm tap water without disinfectant. Appl Env. Microbiol 83, e02737-16. https://doi.org/10.1128/AEM.02737-16

Krustok, I., Truu, J., Odlare, M., Truu, M., Ligi, T., Tiirik, K., Nehrenheim, E., 2015. Effect of lake water on algal biomass and microbial community structure in municipal wastewaterbased lab-scale photobioreactors. Appl Microbiol Biotechnol 99, 6537-49.

Lage, O.M., Bondoso, J., 2014. Planctomycetes and macroalgae, a striking association. Front Microbiol 5.

Largeau, C., Casadevall, E., Berkaloff, C., Dhamelincourt, P., 1980. Sites of accumulation and composition of hydrocarbons in Botryococcus braunii. Phytochemistry 19, 1043-1051.

Lee, J., Cho, D.H., Ramanan, R., Kim, B.H., Oh, H.M., Kim, H.S., 2013. Microalgae-associated bacteria play a key role in the flocculation of Chlorella vulgaris. Bioresour Technol 131, 195-201.

Li, A.H., Zhou, Y.G., 2015. Frigidibacter albus gen nov., sp. nov., a novel member of the family Rhodobacteraceae isolated from lake water. Int J Syst Evol Microbio 65, 1199-206.

Martineau, C., Villeneuve, C., Mauffrey, F., Villemur, R., 2013. Hyphomicrobium nitrativorans sp nov., isolated from the biofilm of a methanol-fed denitrification system treating seawater at the Montreal Biodome. Int. J. Syst. Evol. Microbiol. 63, 3777-3781.

Metzger, P., Berkaloff, C., Casadevall, E., Coute, A., 1985. Alkadiene- and botryococceneproducing races of wild strains of Botryococcus braunii. Phytochemistry 24, 2305-2312. https://doi.org/10.1016/S0031-9422(00)83032-0

Metzger, P., Casadevall, E., 1987. Lycopadiene, a tetraterpenoid hydrocarbon from new strains of the green alga Botryococcus braunii. Tetrahedron Lett. 28, 3931-3934. https://doi.org/10.1016/S0040-4039(00)96423-2

Metzger, P., Casadevall, E., Coute, A., 1988. Botryococcene distribution in strains of the green alga Botryococcus braunii. Phytochemistry 27, 1383-1388.

Metzger, P., Largeau, C., 2005. Botryococcus braunii: a rich source for hydrocarbons and related ether lipids. Appl. Microbiol. Biotechnol. 66, 486-496.

Meyer, D., E, S., Willems, A., 2012. Multilocus sequence analysis of Bosea species and description of Bosea lupini sp nov., Bosea lathyri sp. nov. and Bosea robiniae sp. nov., isolated from legumes. Int J Syst Evol Microbiol 62, 2505-10. 
496

497

498

499

500

501

502

503

504

505

506

507

508

509

510

511

512

513

514

515

516

517

518

519

520

521

522

523

524

525

526

527

528

529

530

531

532

533

534

535

536

537

538

539

540

Moutel, B., Gonçalves, O., Grand, L., F., L., M., S., P., L., J., G., D., Pruvost, J., 1855. Development of a screening procedure for the characterization of Botryococcus braunii strains for biofuel application. Process Biochem. 51.

Newton, R.J., Jones, S.E., Eiler, A., McMahon, K.D., Bertilsson, S., 2011. A guide to the natural history of freshwater lake bacteria. Microbiol. Mol. Biol. Rev. 75, 14-49.

Nonomura, A.M., 1988. Botryococcus braunii var. Showa. USPP6169P.

Oksanen, J., Blanchet, G., F., F., M., K., R., L., P., M., D., M., R., O., B, R., Simpson, G.L., Solymos, P., Stevens, M., H, H., Szoecs, E., Wagner, H., 2016. Vegan: community ecology package.

Otsuka, S., Abe, Y., Fukui, R., Nishiyama, M., Sendoo, K., 2008. Presence of previously undescribed bacterial taxa in non-axenic Chlorella cultures. J. Gen. Appl. Microbiol. 54, 187-93.

Pan, J., Sun, C., Zhang, X.-Q., Huo, Y.-Y., Zhu, X.-F., Wu, M., 2014. Paracoccus sediminis sp. nov., isolated from Pacific Ocean marine sediment. Int. J. Syst. Evol. Microbiol. 64, 25122516.

Posten, C., 2009. Design principles of photo-bioreactors for cultivation of microalgae. Eng. Life Sci. 9, 165-177.

Quast, C., Pruesse, E., Yilmaz, P., Gerken, J., Schweer, T., Yarza, P., Peplies, J., Glöckner, F.O., 2013. The SILVA ribosomal RNA gene database project: improved data processing and web-based tools. Nucleic Acids Res. 41, D590-D596. https://doi.org/10.1093/nar/gks1219

R Core Team, 2014. R: A language and environment for statistical computing. R Found. Stat. Comput.

Ramanan, R., Kang, Z., Kim, B.-H., Cho, D.-H., Jin, L., Oh, H.-M., Kim, H.-S., 2015. Phycosphere bacterial diversity in green algae reveals an apparent similarity across habitats. Algal Res. 8, 140-144. https://doi.org/10.1016/j.algal.2015.02.003

Rivas, M.O., Vargas, P., Riquelme, C.E., 2010. Interactions of Botryococcus braunii cultures with bacterial biofilms. Microb. Ecol. 60, 628-635.

Sambles, C., Moore, K., Lux, T.M., Jones, K., Littlejohn, G.R., Gouveia, J.D., Aves, S.J., Studholme, D.J., Lee, R., Love, J., 2017. Metagenomic analysis of the complex microbial consortium associated with cultures of the oil-rich alga Botryococcus braunii. MicrobiologyOpen 6, e00482. https://doi.org/10.1002/mbo3.482

Satola, B., Wübbeler, J.H., Steinbüchel, A., 2013. Metabolic characteristics of the species Variovorax paradoxus. Appl. Microbiol. Biotechnol. 97, 541-560.

Schwenk, D., Nohynek, L., Rischer, H., 2014. Algae-bacteria association inferred by 16S rDNA similarity in established microalgae cultures. Microbiologyopen 3, 356-368.

Segev, E., Wyche, T.P., Kim, K.H., Petersen, J., Ellebrandt, C., Vlamakis, H., Barteneva, N., Paulson, J.N., Chai, L., Clardy, J., Kolter, R., 2016. Dynamic metabolic exchange governs a marine algal-bacterial interaction. eLife 5.

Shu, Q., Xiong, W., Peng, S., Huang, P., 2011. Molecular progresses of marine Planctomycetes: A review. Afr. J. Microbiol. Res. 5, 6018-6023.

Tanabe, Y., Ioki, M., Watanabe, M.M., 2014. The fast-growing strain of hydrocarbon-rich green alga Botryococcus braunii, BOT-22, is a vitamin B-12 autotroph. J. Appl. Phycol. 26, 913.

Tanabe, Y., Okazaki, Y., Yoshida, M., Matsuura, H., Kai, A., Shiratori, T., Ishida, K., Nakano, S., Watanabe, M.M., 2015. A novel alphaproteobacterial ectosymbiont promotes the growth 
541

542

543

544

545

546

547

548

549

550

551

552

553

554

555

556

557

558

559

560

561

562

563

564

565

566

567

568

569

570

571

572

573

574

575

576

577

578

of the hydrocarbon-rich green alga Botryococcus braunii. Sci. Rep. 5. https://doi.org/10.1038/srep10467

Tang, X., He, L.Y., Tao, X.Q., Dang, Z., Guo, C.L., Lu, G.N., Yi, X.Y., 2010. Construction of an artificial microalgal-bacterial consortium that efficiently degrades crude oil. J. Hazard. Mater. 181, 1158-1162. https://doi.org/10.1016/j.jhazmat.2010.05.033

Tian, L., Scholte, J., Borewicz, K., Bogert, B. van den, Smidt, H., Scheurink, A.J.W., Gruppen, H., Schols, H.A., 2016. Effects of pectin supplementation on the fermentation patterns of different structural carbohydrates in rats. Mol. Nutr. Food Res. 60, 2256-2266. https://doi.org/10.1002/mnfr.201600149

Timmis, K., Qin, J.G., 2010. Hydrocarbons from algae, in: Handbook of Hydrocarbon and Lipid MicrobiologySpringer Berlin Heidelberg. pp. 2817-2826.

Tonon, L.A.C., Moreira, A.P.B., Thompson, F., 2014. The Family Erythrobacteraceae, in: Rosenberg, E., DeLong, E.F., Lory, S., Stackebrandt, E., Thompson, F. (Eds.), The Prokaryotes: Alphaproteobacteria and Betaproteobacteria. Springer Berlin Heidelberg, Berlin, Heidelberg, pp. 213-235. https://doi.org/10.1007/978-3-642-30197-1_376

Ugwu, C.U., Ogbonna, J.C., Tanaka, H., 2005. Light/dark cyclic movement of algal culture (Synechocystis aquatilis) in outdoor inclined tubular photobioreactor equipped with static mixers for efficient production of biomass. Biotechnol. Lett. 27, 75-78.

Volova, T.G., Kalacheva, G.S., Zhilo, N.O., Plotnikov, V.F., 1998. Physiological and biochemical properties of the alga Botryococcus braunii. Russ. J. Plant Physiol. 45, 775-779.

Watanabe, K., Takihana, N., Aoyagi, H., Hanada, S., Watanabe, Y., Ohmura, N., Saiki, H., Tanaka, H., 2005. Symbiotic association in Chlorella culture. Fems Microbiol. Ecol. 51, 187-196.

Weiss, T.L., Roth, R., Goodson, C., Vitha, S., Black, I., Azadi, P., Rusch, J., Holzenburg, A., Devarenne, T.P., Goodenough, U., 2012. Colony organization in the green alga Botryococcus braunii (Race B) is specified by a complex extracellular matrix. Eukaryot. Cell 11, 1424-1440.

Windler, M., Bova, D., Kryvenda, A., Straile, D., Gruber, A., Kroth, P.G., 2014. Influence of bacteria on cell size development and morphology of cultivated diatoms. Phycol. Res. 62, 269-281.

Wolf, F.R., 1983. Botryococcus braunii: an unusual hydrocarbon producing alga. Appl. Biochem. Biotechnol. 8, 249-260.

Yoon, J.-H., Kang, S.-J., Ryu, S.H., Jeon, C.O., Oh, T.-K., 2008. Hydrogenophaga bisanensis sp. nov., isolated from wastewater of a textile dye works. Int. J. Syst. Evol. Microbiol. 58, 393-397.

Zhou, Y., Zhang, Y.-Q., Zhi, X.-Y., Wang, X., Dong, J., Chen, Y., Lai, R., Li, W.-J., 2008. Description of Sinobacter flavus gen. nov., sp. nov., and proposal of Sinobacteraceae fam. nov. Int. J. Syst. Evol. Microbiol. 58, 184-189. 


\section{Figure captions}

580 Fig. 1 Relative abundance of bacterial families in 12 B. braunii strains. Strain abbreviations are used as explained 581 in Table 1. Each bar displays the bacterial family relative abundance above $1 \%$. Strains are labelled below with sample 582 day within square brackets. Bacterial families are organized according to the phyla (in italics) they belong to.

583 Fig. 2 Heatmap of most abundant 16S rRNA gene OTUs belonging to the families Rhizobiaceae, 584 Bradyrhizobiaceae, Comamonadaceae, Erythrobacteraceae and Rhodocyclaceae. The label on the right shows the 585 colour code for the relative abundance. Frequency (average relative abundance) of each OTU is shown in percentage 586 on the right between brackets. The label on the left shows the family level and OTU number followed by genus. n.d 587 means no reads detected.

588 Fig. 3 Non-metric multidimensional scaling (nMDS) ordination (based on Bray-Curtis distance matrix) of 16S

589 rRNA gene sequences of 12 B. braunii strains. a) ordination of all strains with CAEN cultures clustering together 590 (within the ellipse dotted line); b) ordination of the CAEN culture collection strains only. Capital letters in plot b refer 591 to the race subclassification based on the type of hydrocarbons produced. 


\section{Tables Caption}

594 Table 1 Information of the culture collections providers of Botryococcus braunii strains and location of origin.

595 Table 2 NCBI database blast of OTUs for selected families. Closest first three neighbours with highest identity

596 match and with a minimum of $85 \%$ coverage for each OTU. NCBI blast on the 11th February 2016, except the OTU

597662 which the blast search from $30^{\text {th }}$ August 2016 and OTU 63 and 415 on February 2017

598 


\section{Supplementary Information Caption}

600 Supplementary Fig. 1 Hierarchical clustering of $\boldsymbol{B}$. braunii strains. Strains from CAEN culture collection (AC

601 prefix) cluster together in comparison to the other strains.

602 Supplementary Fig. 2 Family taxa relative abundance heatmap of 12 B. braunii strains. On the left, is the family 603 taxa classification. On the right, the colour coded label describes the relative abundance in percentage. 
Figure 1

Relative abundance of bacterial families in $12 \mathrm{~B}$. braunii strains

Strain abbreviations are used as explained in Table 1. Each bar displays the bacterial family relative abundance above $1 \%$. Strains are labelled below with sample day within square brackets. Bacterial Families are organized according to the phyla (in italics) they belong to.

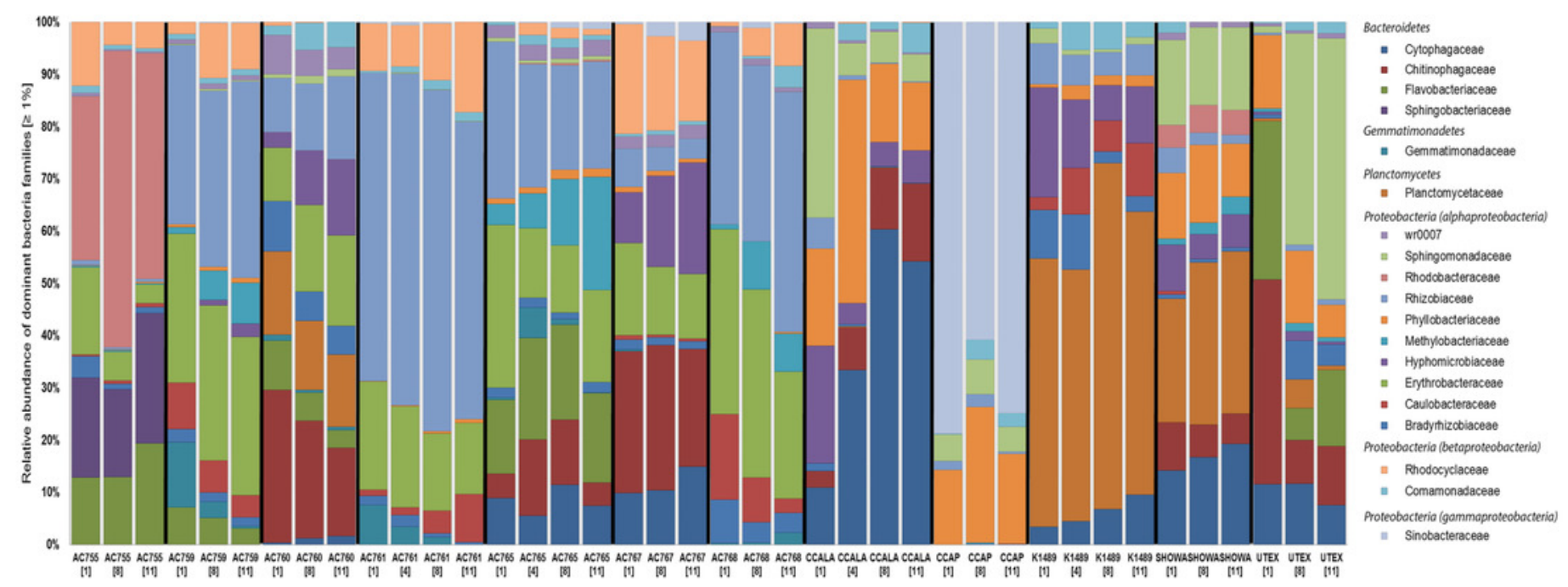


Figure 2

Heatmap of most abundant 16S rRNA gene OTUs

Label on the right show the colour code for the relative abundance. Frequency (average relative abundance) of each OTU is shown in percentage on the right between brackets.

Label on the left shows the family level and OTU number followed by genus. n.d means no reads detected.

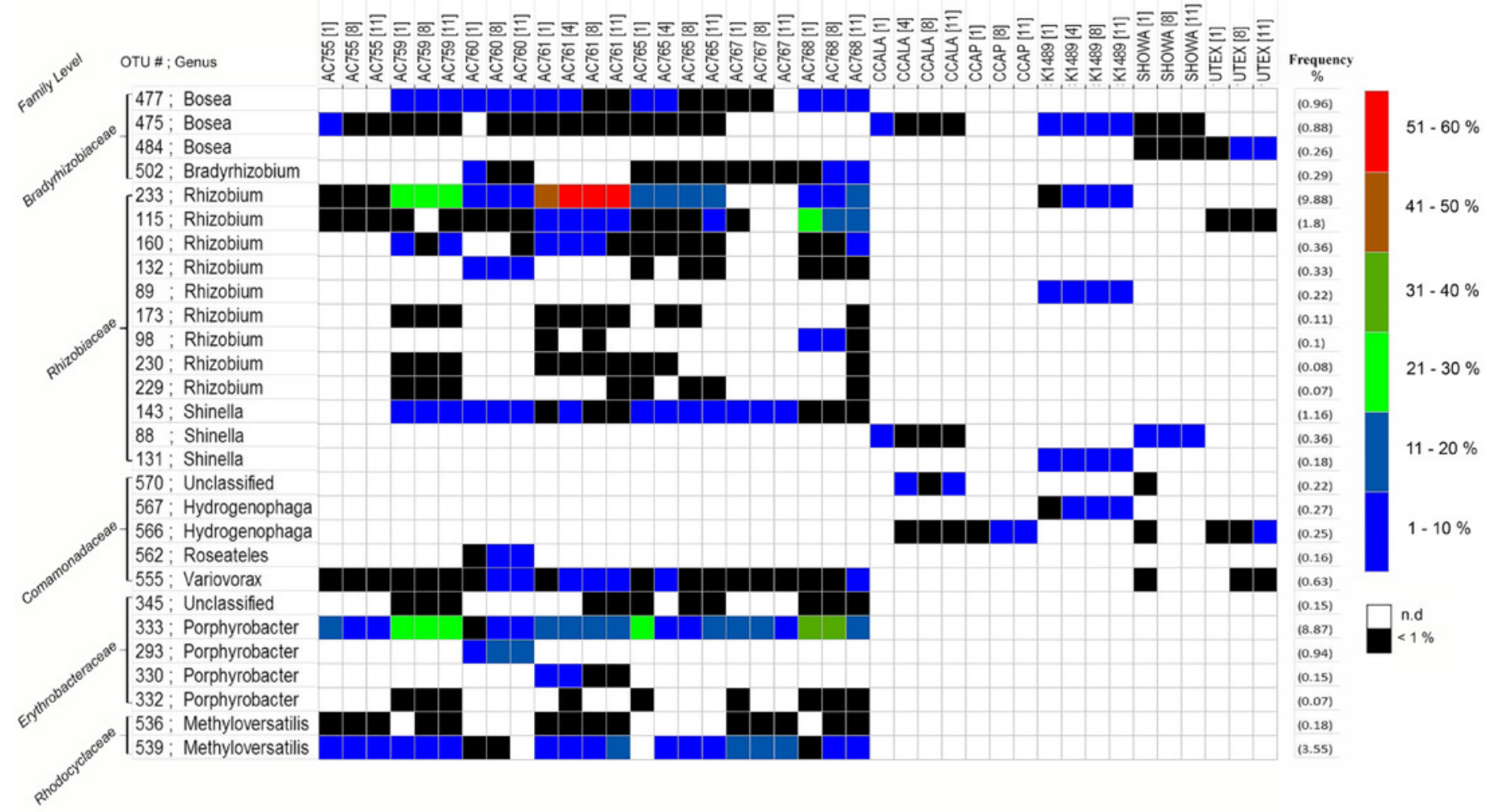


Figure 3

Non-metric multidimensional scaling (nMDS) ordination (based onBray-Curtis distance matrix) of $16 \mathrm{~S}$ rRNA gene sequences of $12 \mathrm{~B}$. braunii strains .

a) ordination of all strains with CAEN cultures clustering together (within the ellipse dotted line); b) ordination of the CAEN culture collection strains only. Capital letters in plot b refer to the race subclassification based on the type of hydrocarbons produced.

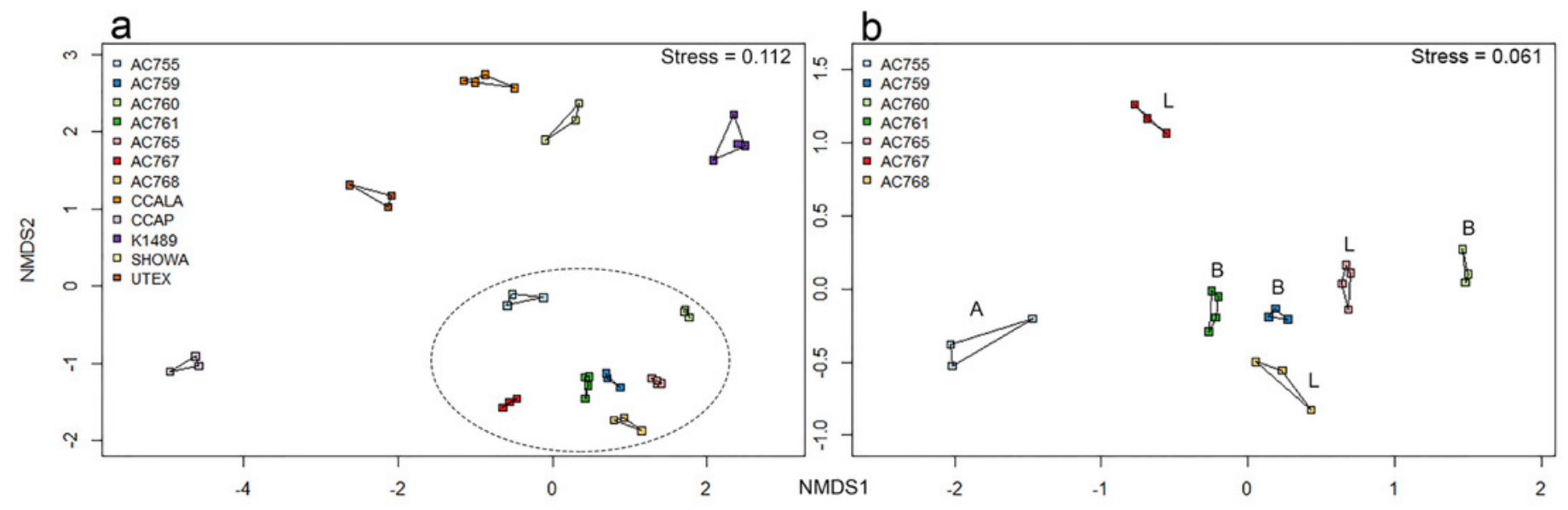




\section{Table $\mathbf{1}$ (on next page)}

Information of the culture collections providersof Botryococcus braunii strains andlocation of origin. 
1 Table 1 Information of the culture collections providers of Botryococcus braunii strains and location of origin.

\begin{tabular}{|c|c|c|c|c|c|}
\hline Culture collection & $\begin{array}{l}\text { Botryococcus braunii } \\
\text { Strain (our } \\
\text { abbreviation) }\end{array}$ & Race & Location & $\begin{array}{l}\text { Isolation, date } \\
\text { of isolation }\end{array}$ & Reference \\
\hline Berkeley & Showa & Race B & $\begin{array}{l}\text { culturing tanks, } \\
\text { Berkley }\end{array}$ & $\begin{array}{l}\text { by unknown, } \\
1980\end{array}$ & $\begin{array}{l}\text { Nonomura, A., } \\
1988\end{array}$ \\
\hline $\begin{array}{l}\text { Scandinavian Culture } \\
\text { Collection of Algae and } \\
\text { Protozoa (SCCAP) }\end{array}$ & K1489 & Race A & Belgium, Nieuwoort & $\begin{array}{l}\text { by G. Hansen, } \\
2008\end{array}$ & No reference \\
\hline $\begin{array}{l}\text { UTEX Culture Collection } \\
\text { of Algae }\end{array}$ & UTEX LB572 (UTEX) & Race A & Cambridge, England & $\begin{array}{l}\text { by M. R. Droop, } \\
1950\end{array}$ & $\begin{array}{l}\text { Eroglu E., et al, } \\
2011\end{array}$ \\
\hline $\begin{array}{l}\text { Culture Collection of } \\
\text { Autotrophic Organisms } \\
\text { (CCALA) check }\end{array}$ & CCALA778 (CCALA) & unknown & $\begin{array}{l}\text { Serra da Estrela } \\
\text { (Barragem da Erva da } \\
\text { Fome) Portugal }\end{array}$ & by Santos, 1997 & $\begin{array}{l}\text { No reference } \\
\text { found }\end{array}$ \\
\hline $\begin{array}{l}\text { Culture Collection of } \\
\text { Algae and Protozoa } \\
\text { (CCAP) }\end{array}$ & CCAP807/2 (CCAP) & Race A & $\begin{array}{l}\text { Grasmere, Cumbria, } \\
\text { England }\end{array}$ & $\begin{array}{l}\text { by Jaworski, } \\
1984\end{array}$ & $\begin{array}{l}\text { Hilton J. et al, } \\
1989\end{array}$ \\
\hline \multirow{7}{*}{ ALGOBANK-CAEN } & AC755 & Race A & $\begin{array}{l}\text { Lingoult-Morvan, } \\
\text { France }\end{array}$ & $\begin{array}{l}\text { by Pierre } \\
\text { Metzger, } 1981\end{array}$ & $\begin{array}{l}\text { Metzger, P., et al, } \\
1985\end{array}$ \\
\hline & AC759 & Race B & Ayame, Ivory Coast & $\begin{array}{l}\text { by Pierre } \\
\text { Metzger, } 1984\end{array}$ & $\begin{array}{l}\text { Metzger, P., et al, } \\
1988\end{array}$ \\
\hline & AC760 & Race B & Kossou, Ivory Coast & $\begin{array}{l}\text { by Pierre } \\
\text { Metzger, } 1984\end{array}$ & $\begin{array}{l}\text { Metzger, P., et al, } \\
1988\end{array}$ \\
\hline & $\mathrm{AC} 761$ & Race B & $\begin{array}{l}\text { Paquemar, Martinique, } \\
\text { France }\end{array}$ & $\begin{array}{l}\text { by Pierre } \\
\text { Metzger, } 1983\end{array}$ & $\begin{array}{l}\text { Metzger, P., et al, } \\
1985\end{array}$ \\
\hline & AC765 & Race L & Kossou, Ivory Coast & $\begin{array}{l}\text { by Pierre } \\
\text { Metzger, } 1984\end{array}$ & $\begin{array}{l}\text { Metzger, P., et al, } \\
1988\end{array}$ \\
\hline & AC767 & Race L & $\begin{array}{l}\text { Songkla Nakarin, } \\
\text { Thailand }\end{array}$ & $\begin{array}{l}\text { by Pierre } \\
\text { Metzger, } 1985\end{array}$ & $\begin{array}{l}\text { Metzger, P., } \\
\text { Casadevall, } \\
\text { E.,1987 }\end{array}$ \\
\hline & AC768 & Race L & $\begin{array}{l}\text { Yamoussoukro, Ivory } \\
\text { Coast }\end{array}$ & $\begin{array}{l}\text { by Pierre } \\
\text { Metzger, } 1984\end{array}$ & $\begin{array}{l}\text { Metzger, P., } \\
\text { Casadevall, } \\
\text { E.,1987 }\end{array}$ \\
\hline
\end{tabular}




\section{Table 2 (on next page)}

NCBI database blast of OTUs for selected families .

Closest first three neighbours with highest identity match and with a minimum of $85 \%$ coverage for each OTU. NCBI blast on the 11th February 2016, except the OTU 662 which the blast search from $30^{\text {th }}$ August 2016 and OTU 63 and 415 on February 2017 
Table 2 NCBI database blast of OTUs for selected families. Closest first three neighbours with highest identity match and with a minimum of $85 \%$ coverage for each OTU. NCBI blast on the 11th February 2016, except the OTU 662 which the blast search from 30th August 2016 and OTU 63 and 415 on February 2017

\begin{tabular}{|c|c|c|c|c|c|}
\hline \multicolumn{2}{|c|}{ OTU nearest neighbour1 } & \multirow{2}{*}{$\begin{array}{l}\begin{array}{l}\text { Genbank } \\
\text { acc. }\end{array} \\
\text { NR_121713.1 Hyphomicrobium nitrativorans (100) }\end{array}$} & \multirow{2}{*}{$\begin{array}{l}\text { Genbank acc. } \\
\text { NR_118448.1 }\end{array}$} & \multirow{2}{*}{$\begin{array}{l}\text { nearest neighbour3 } \\
\text { Bosea lathyri (100) }\end{array}$} & \multirow{2}{*}{$\begin{array}{l}\begin{array}{l}\text { Genbank } \\
\text { acc. }\end{array} \\
\text { NR_108515.1 }\end{array}$} \\
\hline 475 & $\begin{array}{l}\text { Hyphomicrobium nitrativorans } \\
(100)\end{array}$ & & & & \\
\hline 477 & Bradyrhizobium lupini (100) & NR_134836.1 Bradyrhizobium lupini (100) & NR_044869.2 & Rhodopseudomonas palustris (100) & NR_103926.1 \\
\hline 484 & Bosea robiniae (100) & NR_108516.1 Bradyrhizobium lupini (99) & NR_134836.1 & Bradyrhizobium ottawaense (99) & NR_133988.1 \\
\hline 502 & Bradyrhizobium daqingense (100) & NR_118648.1 Bradyrhizobium lablabi (100) & NR_117513.1 & Beijerinckia doebereinerae (100) & NR_116304.1 \\
\hline 88 & Rhizobium rhizoryzae (100) & NR_133844.1 Rhizobium flavum (100) & NR_133843.1 & Rhizobium azibense (100) & NR_133841.1 \\
\hline 115 & Rhizobium rhizoryzae (100) & NR_133844.1 Rhizobium flavum (100) & NR_133843.1 & Rhizobium azibense (100) & NR_133841.1 \\
\hline 143 & Rhizobium rhizoryzae (100) & NR_133844.1 Rhizobium flavum (100) & NR_133843.1 & Rhizobium azibense (100) & NR_133841.1 \\
\hline 233 & Rhizobium paranaense (100) & NR_134152.1 Rhizobium rhizoryzae (100) & NR_133844.1 & Rhizobium flavum (100) & NR_133843.1 \\
\hline 555 & Variovorax guangxiensis (100) & NR_134828.1 Variovorax paradoxus (100) & NR_074654.1 & Variovorax boronicumulans (100) & NR_114214.1 \\
\hline 566 & Hydrogenophaga flava (100) & NR_114133.1 Hydrogenophaga bisanensis (100) & NR_044268.1 & Hydrogenophaga defluvii (100) & NR_029024.1 \\
\hline 567 & Hydrogenophaga flava (100) & NR_114133.1 Hydrogenophaga bisanensis (100) & NR_044268.1 & Hydrogenophaga defluvii (100) & NR_029024.1 \\
\hline 333 & Sphingomonas gei (100) & NR_134812.1 Sphingomonas ginsengisoli (100) & NR_132664.1 & Porphyrobacter colymbi (100) & NR_114328.1 \\
\hline 539 & Uncultured bacterium (100) & KY606782.1 Methyloversatilis discipulorum (71) & KY284088.1 & Methyloversatilis discipulorum (71) & KY284080.1 \\
\hline 63 & Thioclava sp. (100) & CP019437.1 Rhodobacter sp. (100) & KY608089.1 & Uncultured Rhodobacter sp. (100) & KY606875.1 \\
\hline 819 & Dyadobacter jiangsuensis (100) & NR_134721.1 Dyadobacter fermentans (100) & NR_074368.1 & Dyadobacter tibetensis (88) & NR_109648.1 \\
\hline 832 & Dyadobacter jiangsuensis (100) & NR_134721.1 Dyadobacter fermentans (100) & NR_074368.1 & Dyadobacter tibetensis (88) & NR_109648.1 \\
\hline 415 & Uncultured bacterium (100) & KT769749.1 Uncultured bacterium (91) & KT724695.1 & Uncultured Planctomyces sp. (87) & JX576019.1 \\
\hline 45 & Frigidibacter albus (100) & NR_134731.1 Paracoccus sediminis (96) & NR_134122.1 & Nioella nitratireducens (94) & NR_134776.1 \\
\hline 69 & Frigidibacter albus (100) & NR_134731.1 Paracoccus sediminis (100) & NR_134122.1 & Nioella nitratireducens (97) & NR_134776.1 \\
\hline 302 & Sphingorhabdus arenilitoris (100) & NR_134184.1 Sphingopyxis italica (100) & NR_108877.1 & $\begin{array}{l}\text { Parasphingopyxis lamellibrachiae } \\
(100)\end{array}$ & NR_113006.1 \\
\hline 310 & Sphingomonas yantingensis (100) & NR_133866.1 Sphingomonas canadensis (100) & NR_108892.1 & Blastomonas natatoria (100) & NR_113794.1 \\
\hline 355 & Blastomonas natatoria (100) & NR_113794.1 Sphingomonas ursincola (100 & NR_040825.1 & Blastomonas natatoria (100) & NR_040824.1 \\
\hline
\end{tabular}

